\title{
UM HISTORIADOR NO CAMPO
}

MARIANO FEIO ${ }^{1}$

Albert Silbert, um historiador, mas também um geógrafo. Esteve três meses habitando em Beja, a consultar os arquivos, pobres e sobretudo desorganizados. Neste tempo interessou-se também muito pela agricultura regional, ao ponto de escrever um artigo "Le Progrès Agricole dans les Plaines Méditerranéennes: une exploitation modernisée de l'Alentejo", publicado na Revue de Géographie des Pyrénées et du Sud-Ouest (1958, tomo 29, 15 p.)

Apresentam-se, muito resumidamente, os tópicos dos assuntos tratados, relevantes nesse final dos anos 50, para dar ideia da larga visão do geógrafo. Para começar, mostra excelente conhecimento das dificuldades do clima mediterrânico para a agricultura, que, como nota, há tendência para esquecer (40 anos depois acontece o mesmo!); provoca com frequência excessos de chuva de inverno e carências na primavera, e é difícil também pela grande irregularidade, que torna a comparação com a curva média de Adelaide (Austrália), feita por P. Birot, pouco significativa, pois uma coisa são as médias, outra as realidades anuais.

Está bem informado quanto aos escritos de Mira Galvão, um agrónomo formado em Itália, prático, muito competente, que teve grande influência para melhorar a agricultura do Baixo Alentejo. Com ele, distingue entre a agricultura dos "barros", as melhores terras do país para trigo, e a das terras "galegas" (no sentido de pobres), que precisam de anos de pousio.

Refere o desenvolvimento da cultura do trigo no Alentejo, causado no fim do século pela protecção aduaneira, depois pelos preços altos, consequência da primeira Guerra Mundial. Seguiram-se uma crise, de 1920 a 1929, depois os incentivos da "campanha do trigo", que aumentaram as áreas. Aconteceu virem anos de clima muito favorável, de 1932 a 1935, o que levou a um excesso e à única exportação de trigo do país (a um terço do preço interno), para faltar logo no ano seguinte, que foi de grandes chuvas. Se houvesse compreensão das relações clima/trigo, ter-se-ia evitado este prejuízo.

Os técnicos teóricos preocupavam-se então muito com a utopia da estrumação. Silbert reconhece a sua impossibilidade. Apesar de, na exploração que se

1 Professor Universitário Jubilado e Agricultor. Caixa Postal 248. 7900 Canhestros 
aprecia, se ter duplicado o número de ovinos (mercê de alimentação conservada no inverno), para estrumar as terras de $4 \mathrm{em} 4$ anos seria preciso multiplicar a quantidade deste gado por 8. Aproveitava-se, todavia, todo o estrume possível, mudando as ovelhas de redil a meio da noite (com o que estrumavam o dobro) e misturando o estrume com terra, para não ficar exposto ao sol, logo na manhã seguinte. Estrumar grandes áreas, só com vacas de leite estabuladas, como em Israel, o que implicava um consumo destes produtos que não existia no país, e ainda hoje não existe.

Por isso, os técnicos se voltavam, e muito bem, para as estrumações verdes (enterrar leguminosas). Procurava-se uma "leguminosa milagre", capaz de suportar o clima (as leguminosas são muito sensíveis ao encharcamento), de enriquecer o solo e de alimentar o gado. O nosso historiador vai buscar Catão, que já sugeria tremoços, favas e ervilhacas. Cita ainda o célebre agrónomo José Maria Grande, que já em 1849 aconselhava a enterrar plantas verdes como adubos (siderações); um século depois Mira Galvão preconiza enterrar tremocilha. O relatório dos peritos da OCDE, com quem Silbert conviveu e foi ao campo, aconselha a procurar leguminosas no Mediterrâneo Oriental, cita muitas espécies que não resultaram entre nós, mas duas ervilhacas foram usadas para feno e silagem na exploração estudada. Contudo, empregou-se muita sideração de tremocilha; no primeiro ano em que se usou, em 1956, um ano muito chuvoso, os resultados foram tão espectaculares (o trigo sobre sideração produziu mais do dobro do restante) que a prática ficou implantada.

$\mathrm{Na}$ exploração em apreciação, Silbert começa por referir o que era a agricultura antes da grande mudança, ocasião para descrever o sistema tradicional: alqueive, trigo, aveia, pousio de 1 ou 2 anos. Rendimento do trigo de $500-1000 \mathrm{~kg} / \mathrm{ha}$ (de 1944 a 1954 apenas 560 kg/ha de média). Não havia regadio. Cerca de 500 a 600 ovelhas, em regime extensivo (sem complemento alimentar na época sem pastagem). Porcos no montado. Trabalhos agrícolas, tudo a braço e com gado (sobretudo os pachorrentos bois). Ceifa à mão. Variedades de trigo tradicionais. Adubação insuficiente.

O novo regime: mecanização total, com 3 tractores e todas as alfaias, incluindo semeadores; também ceifeira-debulhadora. Regadio ( 2 barragens) onde o arroz resultou muito bem. O rebanho de ovelhas duplicou (com alimentação complementar de feno, silagem e palha na época morta); cobrição permanente, para tentar aumentar o número de crias. Grande melhoria da técnica da cultura do trigo: variedades italianas híbridas, adubações azotadas em cobertura (ao tempo pouco praticadas) e siderações de tremocilha, cujos resultados foram mais modestos do que no primeiro ano (aumento da produção de uns $300-400 \mathrm{~kg} / \mathrm{ha}$ ), mas continuaram sempre, apesar das dificuldades, acamamento, por ser um choque de azoto repentino e demasiado forte.

Estas modificações resultaram, em especial a mecanização e a melhoria da cultura do trigo. Outras foram duvidosas ou neutras no aspecto económico, como o regadio (vantajoso no aspecto social) e o aumento do número de ovelhas. Outras deram prejuízo, como algumas forragens (serradela, grão-da-Gramicha e forragens 
regadas). Foram logo abandonadas.

A exploração, quando Silbert a conheceu, estava ainda em transformação e acertos. O plano inicial tinha sido idealista, no sentido de tentar pôr em prática as ideias de técnicos que não conheciam os aspectos económicos, nomeadamente com excesso de forragens cultivadas e leguminosas (como serradela, grão-da-Gramicha e couves regadas) que uma boa contabilidade analítica mostrou logo que não eram rentáveis e foram abandonadas. Nesta situação, Silbert é prudente e refere em especial o êxito da rotação 1) alqueive, 2) trigo, 3) sideração de tremocilha, 4) trigo.

Voltando ao Alentejo em geral, os peritos da OCDE aconselham suprimir a cultura nas terras pobres e substituí-la por pastagens melhoradas e floresta, ignorando que a instalação de montados de sobro e de azinho é ruinosa por causa da grande lentidão de crescimento destas árvores

O Alentejo sofreu durante muito tempo de falta de mão-de-obra, que vinha da Beira e do Algarve, mas agora tem excesso, com crises de desemprego (o trabalho nos cereais é muito irregular, ocupa muita gente, mas só na monda e na ceifa). Previa-se então o aumento do desemprego por causa da mecanização. Silbert entende que a dimensão da propriedade não é responsável pelas dificuldades, pelo contrário traz economias de escala que permitem resistir a condições difíceis. A situação do Alentejo, segundo ele, depende do desenvolvimento e industrialização do país, que crie mercado para produtos mais ricos e obvie à situação de então, com $47,5 \%$ da população activa na agricultura.

Planeia-se em 1956 grande desenvolvimento do regadio, mas Silbert acentuou dificuldades que realmente se verificaram: arroz demais, citrinos, em que técnicos tinham posto grandes esperanças, prejudicados pelas geadas, tabaco e beterraba proibidos para colocar os produtos das colónias, etc. Para terminar, breve referência à vinha, já então em situação igual à actual: só por si resolveria os problemas da agricultura portuguesa, em especial da mão-de-obra, mas as situações de excesso, tanto do mercado nacional, como do internacional, fariam desta orientação um verdadeiro "non-sens". 